\title{
Evaluation of prognostic factors in lung cancers with surgical complete response after induction treatment
}

\author{
Indüksiyon tedavisi sonrasında cerrahi patolojik tam yanıt alınan akciğer kanserlerinde \\ prognostik faktörlerin değerlendirilmesi
}

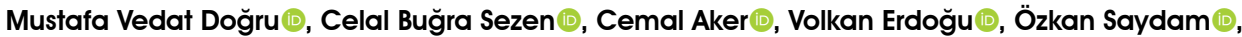 \\ Aysun Ölçmen ${ }^{(1)}$, Levent Cansever ${ }^{-1}$, Muzaffer Metin $(1)$
}

Department of Thoracic Surgery, Yedikule Chest Diseases and Thoracic Surgery Training and Research Hospital, Istanbul, Turkey

\begin{abstract}
Background: This study aims to evaluate long-term results of induction treatment and to investigate prognostic factors affecting survival in non-small cell lung cancer patients with a pathological complete response.

Methods: Between January 2010 and December 2017, a total of 39 patients (38 males, 1 female; mean age: $56.2 \pm 8.3$ years; range, 38 to 77 years) having locally advanced (IIIA-IIIB) non-small cell lung cancer who were given induction treatment and underwent surgery after induction treatment and had a pathological complete response were retrospectively analyzed. Survival rates of the patients and prognostic factors of survival were analyzed.
\end{abstract}

Results: Clinical staging before induction treatment revealed Stage IIB, IIIA, and IIIB disease in three (7.7\%), 26 (66.7\%), and $10(25.6 \%)$ patients, respectively. The five-year overall survival rate was $61.2 \%$, and the disease-free survival rate was $55.1 \%$. In nine $(23.1 \%)$ patients, local and distant recurrences were detected in the postoperative period.

Conclusion: In patients with locally advanced non-small cell lung cancer undergoing surgery after induction treatment, the rates of pathological complete response are at considerable levels. In these patients, the five-year overall survival is quite satisfactory and the most important prognostic factor affecting overall survival is the presence of single-station N2.

Keywords: Induction treatment, lung cancer, pathological complete response.

\section{$\ddot{O} Z$}

Amaç: Bu çalışmada, patolojik tam yanıt veren küçük hücreli dışı akciğer kanserli hastalarda indüksiyon tedavisinin uzun dönem sonuçları değerlendirildi ve sağkalımı etkileyen prognostik faktörler araştırıldı.

Çalışma planı: Ocak 2010 ve Aralık 2017 tarihleri arasında indüksiyon tedavisi verilen ve indüksiyon tedavisinden sonra ameliyat edilen ve patolojik tam yanıt veren ileri evre (IIIA-IIIB) küçük hücreli dışı akciğer kanseri olan toplam 39 hasta (38 erkek, 1 kadın; ort. yaş: $56.2 \pm 8.3$ yıl; dağ 1 lım 38-77 yıl) retrospektif olarak incelendi. Hastaların sağkalım oranları ve sağkalımın prognostik faktörleri değerlendirildi.

Bulgular: İndüksiyon tedavisi öncesi klinik evrelemede üç (\%7.7) hastada Evre IIB, 26 (\%66.7) hastada Evre IIIA, ve 10 (\%25.6) hastada Evre IIIB hastalık izlendi. Beş yıllık sağkalım oranı \%61.2 olup, hastalıksız sağkalım oranı \%55.1 idi. Dokuz (\%23.1) hastada, ameliyat sonrası dönemde lokal nüks veya uzak nüks saptandi.

Sonuç: Indüksiyon tedavisi sonrası ameliyat edilen lokal ileri evre küçük hücreli dişı akciğer kanserli hastalarda, patolojik tam yanıt oranı azımsanamayacak düzeydedir. $\mathrm{Bu}$ hastalarda beş yıllık genel sağkalım oldukça memnun edici olup, genel sağkalımı etkileyen en önemli prognostik faktör tek istasyon N2 varlığıdır.

Anahtar sözcükler: İndüksiyon tedavisi, akciğer kanseri, patolojik tam yanit.

Received: April 29, 2020 Accepted: June 13, 2020 Published online: April 26, 2021

Correspondence: Mustafa Vedat Doğru, MD. Yedikule Göğüs Hastalıkları ve Göğüs Cerrahisi Eğitim ve Araştırma Hastanesi, Göğüs Cerrahisi Kliniği, 34020 Zeytinburnu, İstanbul, Türkiye. Tel: +90 212 - 4090200 e-mail: drmvedatdogru@hotmail.com 
The management of locally advanced (IIIA-IIIB) non-small cell lung cancer (NSCLC) is challenging, and there are different options with proven efficacy in the literature. ${ }^{[1]}$ Currently, the widely adopted clinical approach is multimodal treatment methods; however, the debate regarding the standard treatment protocol is still ongoing. Reasons for obscuring the optimal treatment approach are as follows: (i) the limited number of clinical studies and limited patient populations, (ii) the heterogeneity of disease presentations, and (iii) differences in induction treatment (IT). Despite all of the above, surgery performed after IT (chemotherapy [CHT] and radiotherapy $[\mathrm{RT}]$ ) has taken its place as a positive prognostic factor among multimodal treatments, as suggested by many centers..$^{[2-9]}$ Following IT, patients with a complete or partial response, downstaged or stable disease, or patients with radiological findings suggesting technically resectable disease are eligible for surgery. Better survival and lower recurrence rates have been shown to be associated with downstaging. ${ }^{[3]}$

The group of patients undergoing surgery after being deemed resectable in accordance with the clinical restaging, with the outcome of pathological complete response (pCR) is small; however, these patients are the optimal candidates for long-term survival. In the literature, there are few studies including this subgroup, and many important details still remain undefined and the relevant debate continues. ${ }^{[10]}$

In the present study, we aimed to analyze in detail the clinical and pathological features of patients with pCR who were staged clinically as having locally advanced NSCLC and underwent surgery after being deemed as being resectable following IT and to identify factors affecting survival and recurrence.

\section{PATIENTS AND METHODS}

This single-center, retrospective study was conducted at Yedikule Chest Diseases and Thoracic Surgery Training and Research Hospital, Department of Thoracic Surgery between January 2010 and December 2017. A total of 187 patients who were given IT for locally advanced (IIIA-IIIB) NSCLC and underwent surgery after IT were screened. A total of 39 patients ( 38 males, 1 female; mean age: $56.2 \pm 8.3$ years; range, 38 to 77 years) with pCR who underwent surgical resection after IT were included in the study. A written informed consent was obtained from each patient. The study protocol was approved by the Istanbul Training and Research Hospital Ethics Committee (date/no: 27.09.2019/2008). The study was conducted in accordance with the principles of the Declaration of Helsinki.

\section{Clinical stage}

All tumors in all patients included were evaluated using preoperative thoracic computed tomography (CT). Positron emission tomography (PET)-CT, cranial magnetic resonance imaging (MRI), and upper abdominal CT were performed in all patients to evaluate distant metastases. In patients suspected of having mediastinal lymph node metastases with radiological imaging methods (CT, PET-CT), procedures such as endobronchial ultrasound (EBUS), mediastinoscopy, and mediastinotomy were performed for disease staging. The 2009 International Association for the Study of Lung Cancer (IASLC) Lymph Node Map was used for the classification of mediastinal lymph nodes. ${ }^{[1]}$ The patients with resectable $\mathrm{pN} 2$ disease (single-station or multiple stations) and superior sulcus tumors underwent IT. The T4 tumors were assigned as tumors with a diameter of $7 \mathrm{~cm}$ and above in six patients, and tumors invading the carina in one patient. Histopathological evaluations were performed in accordance with the eight edition of the IASLC staging guidelines. ${ }^{[12]}$

\section{IT and restaging}

The IT consisted of double combined treatments with platinum-based CHT agents (platinum/taxane) given every other week for two to six courses. Seven patients were only given induction CHT, and 32 patients were given $\mathrm{CHT}+\mathrm{RT}$ concurrently. The RT was given at a dose of 45 to 54 Gy before 2014, and full-dose RT consisting of 60 to 66 Gy was given after 2014 . Preoperative CHT or CHT+RT was planned based on the common decision of the Oncological Tumor Board. The CHT+RT was given for patients with superior sulcus tumors, and CHT was preferred in the foreground according to the Multidisciplinary Council decision in patients with central tumors. The decision of the oncological tumor board, the response of the patients with a central tumor was evaluated with thoracic CT scan after two cycles of CHT. The operation was planned for patients with tumor regression on thoracic CT after IT. Adjuvant therapy was given to 10 patients to complete the postoperative CHT dose.

The patients were evaluated four to six weeks after IT through radiological methods (CT, PET-CT), and all patients with resectable disease who had downstaging and stable disease underwent EBUS or mediastinoscopy for restaging. The patients who were defined as N2 with EBUS before the treatment underwent restaging 
with mediastinoscopy, and those who were defined as N2 with mediastinoscopy before the treatment underwent restaging with EBUS. Following the IT, the patients who were defined as not having $\mathrm{pN} 2$ with invasive methods underwent surgery.

\section{Preoperative evaluation and surgical methods}

A preoperative routine blood panel, along with pulmonary function tests, electrocardiogram, and blood gases were performed to evaluate pulmonary and cardiac reserves. In patients with low forced expiratory volume in one second (FEV1), diffusion capacity of the lung for carbon monoxide (DLCO) test, and lung perfusion scintigraphy were also performed. Before surgery, fiberoptic bronchoscopy was performed to evaluate the endobronchial lesion and establish a diagnosis. All patients were evaluated by the Multidisciplinary Oncological Tumor Board. The Charlson Comorbidity Index (CCI) was used to assess comorbidities. ${ }^{[13]}$

In all patients, lobectomy or pneumonectomy, along with open thoracotomy was used as the surgical approach. During surgery, systematic, complete mediastinal lymph node dissection was performed following the planned anatomic resection. In rightsided tumors, sampling was performed at the $2^{\text {nd }}, 4^{\text {th }}$, and 7 to $9^{\text {th }}$ lymph node stations, and in left-sided tumors, the 5 to $9^{\text {th }}$ lymph node stations were sampled. Complete (R0) resection was performed in a tumor freeway at the proximal ends and the mediastinal lymph nodes. In the surgical specimen, no residual tumor tissue and no disease in the dissected mediastinal lymph nodes, both macro- and microscopically, was defined as yP (TONOM0) pCR.

\section{Postoperative follow-up}

Mortality was defined as death events during the hospitalization period and within 90 days of hospital discharge. Follow-ups were performed with physical examination and thoracic CT once every three months for the first two years, every six months at two to five years, and once a year thereafter. Ten patients were given adjuvant CHT. In patients with recurrence, the patterns of recurrence were evaluated using methods such as PET-CT, bronchoscopy, EBUS, fine needle aspiration biopsy, and scalene lymph node biopsy.

Local recurrence at follow-up was defined as recurrence of ipsilateral lung lesions, mediastinal involvement, and recurrence in the bronchial stump. Distant recurrences were defined as the development of tumors in the brain, liver, bone, contralateral lung, and adrenal glands.
Table 1. Demographic and histopathological features of patients

\begin{tabular}{|c|c|c|c|}
\hline Variables & $\mathrm{n}$ & $\%$ & Mean \pm SD \\
\hline Age (year) & & & $56.2 \pm 8.4$ \\
\hline$<65$ & 35 & 89.7 & \\
\hline$\geq 65$ & 4 & 10.3 & \\
\hline \multicolumn{4}{|l|}{ Sex } \\
\hline Male & 38 & 97.4 & \\
\hline Female & 1 & 2.6 & \\
\hline \multicolumn{4}{|l|}{ Charlson Comorbidity Index } \\
\hline 2 & 21 & 53.8 & \\
\hline 3 & 13 & 33.3 & \\
\hline 4 & 2 & 5.1 & \\
\hline 5 & 3 & 7.7 & \\
\hline \multicolumn{4}{|l|}{ cT Stage } \\
\hline $\mathrm{T} 1$ & 2 & 5.1 & \\
\hline $\mathrm{T} 2$ & 8 & 20.5 & \\
\hline $\mathrm{T} 3$ & 22 & 56.4 & \\
\hline $\mathrm{T} 4$ & 7 & 17.9 & \\
\hline \multicolumn{4}{|l|}{ cN Stage } \\
\hline No & 4 & 10.3 & \\
\hline N1 & 14 & 35.9 & \\
\hline $\mathrm{N} 2$ & 21 & 53.8 & \\
\hline \multicolumn{4}{|l|}{ cTNM } \\
\hline IIB & 3 & 7.7 & \\
\hline IIIA & 26 & 66.7 & \\
\hline IIIB & 10 & 25.6 & \\
\hline \multicolumn{4}{|l|}{ Lymph node involvement } \\
\hline Single station & 16 & 41 & \\
\hline Multiple stations & 5 & 12.8 & \\
\hline Days from IT to surgery & & & $40.6 \pm 6.5$ \\
\hline \multicolumn{4}{|l|}{ yTNM } \\
\hline IA2 & 8 & 20.5 & \\
\hline IA3 & 2 & 5.1 & \\
\hline IB & 6 & 15.4 & \\
\hline IIA & 4 & 10.3 & \\
\hline IIB & 18 & 46.2 & \\
\hline IIIA & 1 & 2.5 & \\
\hline \multicolumn{4}{|l|}{ Resection type } \\
\hline Lobectomy & 26 & 66.7 & \\
\hline Pneumonectomy & 13 & 33.3 & \\
\hline \multicolumn{4}{|l|}{ Histology } \\
\hline Adenocarcinoma & 12 & 30.8 & \\
\hline Squamous cell carcinoma & 27 & 69.2 & \\
\hline \multicolumn{4}{|l|}{ Chemotherapeutic agents } \\
\hline Docetaxel + cisplatin & 5 & 12.8 & \\
\hline Paclitaxel + cisplatin & 13 & 33.3 & \\
\hline Paclitaxel + carboplatin & 15 & 38.5 & \\
\hline Etoposide + cisplatin & 6 & 15.4 & \\
\hline \multicolumn{4}{|l|}{ IT chemotherapy cycles } \\
\hline 2 & 10 & 25.6 & \\
\hline $4-6$ & 29 & 74.4 & \\
\hline \multicolumn{4}{|l|}{ IT Radiotherapy dose } \\
\hline$\leq 60$ Gray & 19 & 59.4 & \\
\hline$>60$ Gray & 13 & 40.6 & \\
\hline Lymph node removed & & & $14.8 \pm 8.4$ \\
\hline \multicolumn{4}{|c|}{ Number of removed lymph nodes } \\
\hline$<10$ & 10 & 25.6 & \\
\hline$>10$ & 29 & 74.4 & \\
\hline \multicolumn{4}{|l|}{ Adjuvant therapy } \\
\hline None & 29 & 74.4 & \\
\hline Chemotherapy alone & 10 & 25.6 & \\
\hline
\end{tabular}

SD: Standard deviation; CCI; Charlson Comorbidity Index, IT; Induction treatment. 
Demographic data, length of hospital stay, mortality, histopathological characteristics, recurrence rates, and overall survival (OS) and disease-free survival (DFS) rates at five years were analyzed.

\section{Statistical analysis}

Statistical analysis was performed using the IBM SPSS version 22.0 software (IBM Corp., Armonk, NY, USA). Continuous variables were presented in mean \pm standard deviation (SD) or median (min-max), while categorical variables were presented in number and frequency. Demographic and clinical characteristics such as age and length of hospitalization were tested for normal distribution using the Kolmogorov-Smirnov test. The independent t-test was used to compare the group means for these variables, and the chi-square test was used to compare morbidity between two groups. Risk analysis affecting mortality was evaluated by

Table 2. Risk factors affecting mortality in the first 90 days

\begin{tabular}{|c|c|c|c|c|c|}
\hline & \multicolumn{2}{|c|}{ Mortality negative } & \multicolumn{2}{|c|}{ Mortality positive } & \multirow[b]{2}{*}{$p$} \\
\hline & $\mathrm{n}$ & $\%$ & $\mathrm{n}$ & $\%$ & \\
\hline Age (year) & & & & & 0.475 \\
\hline$<65$ & 31 & 88.6 & 4 & 100 & \\
\hline$\geq 65$ & 4 & 11.4 & 0 & 0 & \\
\hline Sex & & & & & 0.732 \\
\hline Male & 34 & 97.1 & 4 & 100 & \\
\hline Female & 1 & 2.9 & 0 & 0 & \\
\hline Side & & & & & 0.609 \\
\hline Left & 12 & 34.3 & 2 & 50 & \\
\hline Right & 23 & 65.7 & 2 & 50 & \\
\hline Charlson Comorbidity Index & & & & & 0.318 \\
\hline 2 & 20 & 57.1 & 1 & 25 & \\
\hline$>2$ & 15 & 42.9 & 3 & 75 & \\
\hline Induction treatment & & & & & 0.323 \\
\hline CHT & 7 & 20 & 0 & 0 & \\
\hline CHT-RT & 28 & 80 & 4 & 100 & \\
\hline Induction treatment chemotherapy cycles & & & & & 0.556 \\
\hline 2 & 10 & 28.6 & 0 & 0 & \\
\hline $4-6$ & 25 & 71.4 & 4 & 100 & \\
\hline Radiotherapy dose & & & & & 0.279 \\
\hline$\leq 60$ Gy & 18 & 64.3 & 1 & 25 & \\
\hline$>60$ Gy & 10 & 35.7 & 3 & 75 & \\
\hline yTNM & & & & & 0.179 \\
\hline I & 16 & 45.7 & 0 & 0 & \\
\hline II & 18 & 51.4 & 4 & 100 & \\
\hline III & 1 & 2.9 & 0 & 0 & \\
\hline Resection & & & & & 0.099 \\
\hline Lobectomy & 25 & 71.4 & 1 & 25 & \\
\hline Pneumonectomy & 10 & 28.6 & 3 & 75 & \\
\hline Histopathology & & & & & 0.792 \\
\hline Adenocarcinoma & 11 & 31.4 & 1 & 25 & \\
\hline $\mathrm{SqCC}$ & 24 & 68.6 & 3 & 75 & \\
\hline Adjuvant & & & & & 0.556 \\
\hline Negative & 25 & 71.4 & 4 & 100 & \\
\hline Positive & 10 & 28.6 & 0 & 0 & \\
\hline
\end{tabular}

CHT: Chemotherapy; RT: Radiotherapy; Gy: Gray; SqCC: Squamous Cell Carcinoma; yTNM: Tumor, nodes, and metastases after induction therapy. 
chi-square test. Survival probabilities were estimated using the Kaplan-Meier method. A $p$ value of $<0.05$ was considered statistically significant.

\section{RESULTS}

Of the patients, four (10.3\%) were aged $\geq 65$ years, and the remaining $35(89.7 \%)$ were aged $<65$ years. The tumor was left-sided in $14(35.9 \%)$ patients and right-sided in the remaining $25(64.1 \%)$ patients. The IT was given to $21(53.8 \%)$ patients for N2 disease and to $18(46.2 \%)$ patients for tumor invasion. In 21 patients with N2 disease, the diagnosis was made through EBUS, anterior mediastinotomy, mediastinoscopy, and PET-CT in six, one, nine, and five patients, respectively. Histopathological examinations revealed that $16(41 \%)$ patients were single-station N2 positive, while the remaining five (12.8\%) were multiple-station $\mathrm{N} 2$. In three patients, clinical downstaging could not be determined following IT. In patients with pNO disease, EBUS and mediastinoscopy after IT were performed in nine and 30 patients, respectively for restaging. The median number of CHT cycles was four (range, 2 to 6 ). Demographic and histopathological features of the patients are given in Table 1 .

The IT included CHT + RT in $32(82.1 \%)$ patients, and CHT only was given in the remaining seven (17.9\%) patients. Pneumonectomy was performed in $13(33.3 \%)$ patients, and lobectomy was preferred in the remaining $26(66.7 \%)$ patients. Carinal sleeve pneumonectomy and chest wall resection was

Table 3. Evaluation of prognostic factors affecting survival

\begin{tabular}{|c|c|c|c|c|}
\hline & $\begin{array}{c}5 \text {-year OS } \\
(\%)\end{array}$ & $\begin{array}{l}\text { Mean survival } \\
\text { (months) }\end{array}$ & $95 \% \mathrm{CI}$ & $p$ \\
\hline Age (year) & & & & 0.337 \\
\hline$<65$ & 62.7 & 75 & $61-90$ & \\
\hline$\geq 65$ & 50 & 53 & $11-94$ & \\
\hline Resection type & & & & 0.113 \\
\hline Lobectomy & 67.6 & 81 & $65-96$ & \\
\hline Pneumonectomy & 51.3 & 53 & $30-76$ & \\
\hline Side & & & & 0.307 \\
\hline Left & 55.1 & 58 & $37-79$ & \\
\hline Right & 65.1 & 79 & $61-95$ & \\
\hline Charlson Comorbidity Index & & & & 0.377 \\
\hline 2 & 66.4 & 80 & $62-97$ & \\
\hline$>2$ & 55 & 58 & $39-76$ & \\
\hline Induction treatment & & & & 0.597 \\
\hline CHT & 68.6 & 74 & $51-98$ & \\
\hline CHT-RT & 59.7 & 72 & $55-88$ & \\
\hline Histopathology & & & & 0.700 \\
\hline Adenocarcinoma & 56.3 & 52 & $35-73$ & \\
\hline Squamous cell carcinoma & 63 & 75 & $58-91$ & \\
\hline Adjuvant & & & & 0.497 \\
\hline Negative & 58.2 & 70 & $52-87$ & \\
\hline Positive & 68.6 & 74 & $53-94$ & \\
\hline $\mathrm{cN} 2$ & & & & 0.005 \\
\hline Single cN2 & 76.7 & 91 & $76-106$ & \\
\hline Multiple cN2 & 40 & 28 & $15-41$ & \\
\hline Induction treatment chemotherapy cycles & & & & 0.519 \\
\hline 2 & 68.6 & 74 & $53-94$ & \\
\hline $4-6$ & 58.7 & 70 & $53-88$ & \\
\hline IT Radiotherapy dose & & & & 0.847 \\
\hline$\leq 60 \mathrm{~Gy}$ & 60.5 & 73 & $54-92$ & \\
\hline$>60$ Gy & 64.1 & 34 & $23-45$ & \\
\hline
\end{tabular}

OS: Overall survival; CI: Confidence interval; CHT: Chemotherapy; RT: Radiotherapy; IT: Induction treatment; Gy: Gray. 
performed in one (7.6\%) patient each. Chest wall resection was performed in $11(42 \%)$ of 26 patients who underwent lobectomy.

Histopathology revealed an adenocarcinoma in $12(30.8 \%)$ patients and squamous cell carcinoma (SqCC) in $27(69.2 \%)$ patients. Mortality was encountered in the first 90 days in four (10.3\%) patients. Risk factors affecting mortality in the first 90 days are given in Table 2 .

Lymph nodes at an average of six stations were sampled intraoperatively. The mean number of removed lymph nodes was $14.8 \pm 8.4$. The mean follow-
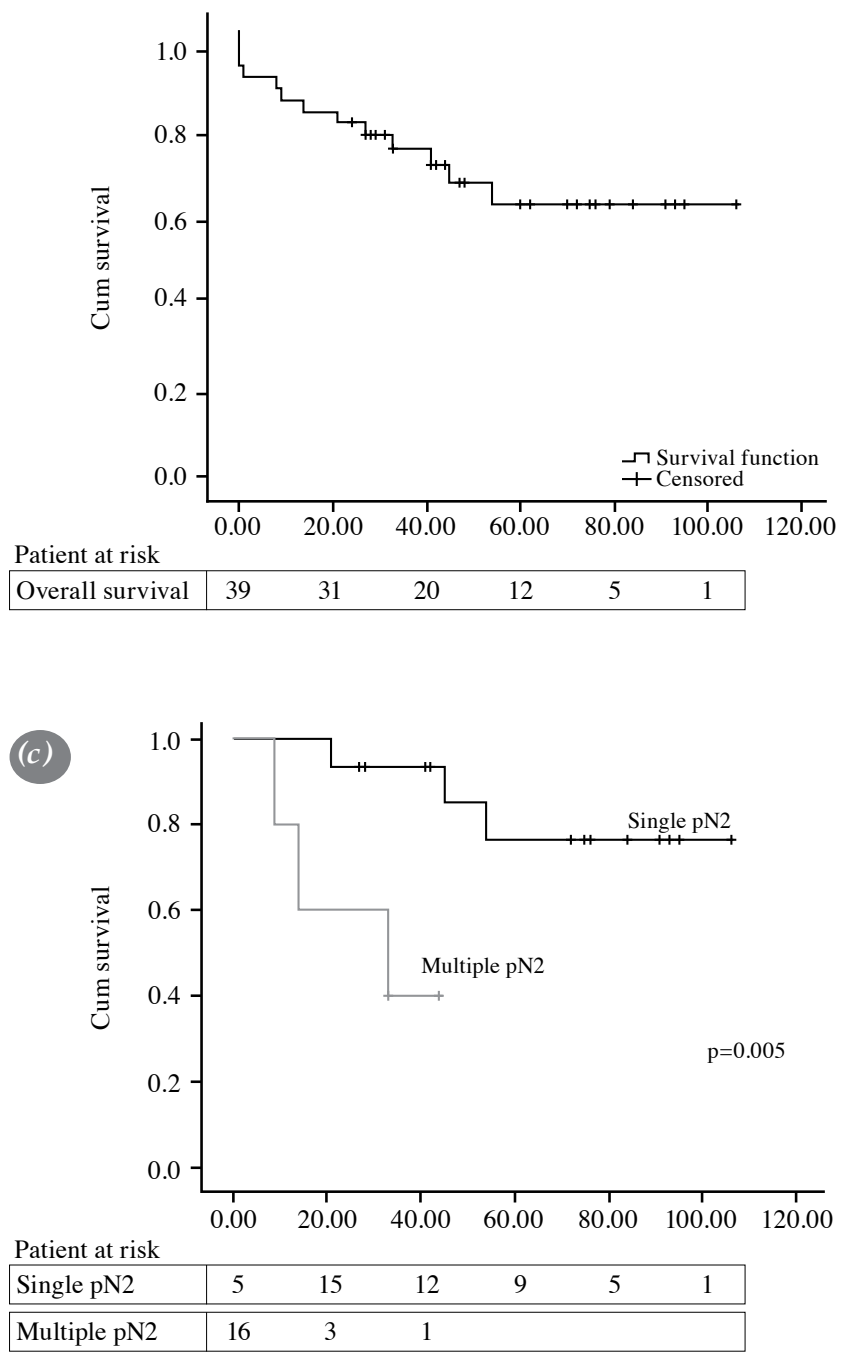

up was $45.0 \pm 30$ (range, 0 to 106) months. The mean OS was $73.8 \pm 7.2$ (95\% CI: 59,6-88.0) months, and the mean five-year OS was $73.8 \pm 7.2$ months. When IT was analyzed, neither CHT nor CHT+RT showed any significant effect on OS $(\mathrm{p}=0.597)$. Factors affecting OS are given in Table 3. The OS of patients with single-station $\mathrm{pN} 2$ was better than in patients with multiple-station $\mathrm{pN} 2(\mathrm{p}=0.005)$ (Figure 1).

Local $(n=3,7.7 \%)$ or distant $(n=6,15.4 \%)$ recurrences were detected in a total of nine $(23.1 \%)$ patients. Local recurrences were in the form of mediastinal recurrence in two patients and ipsilateral
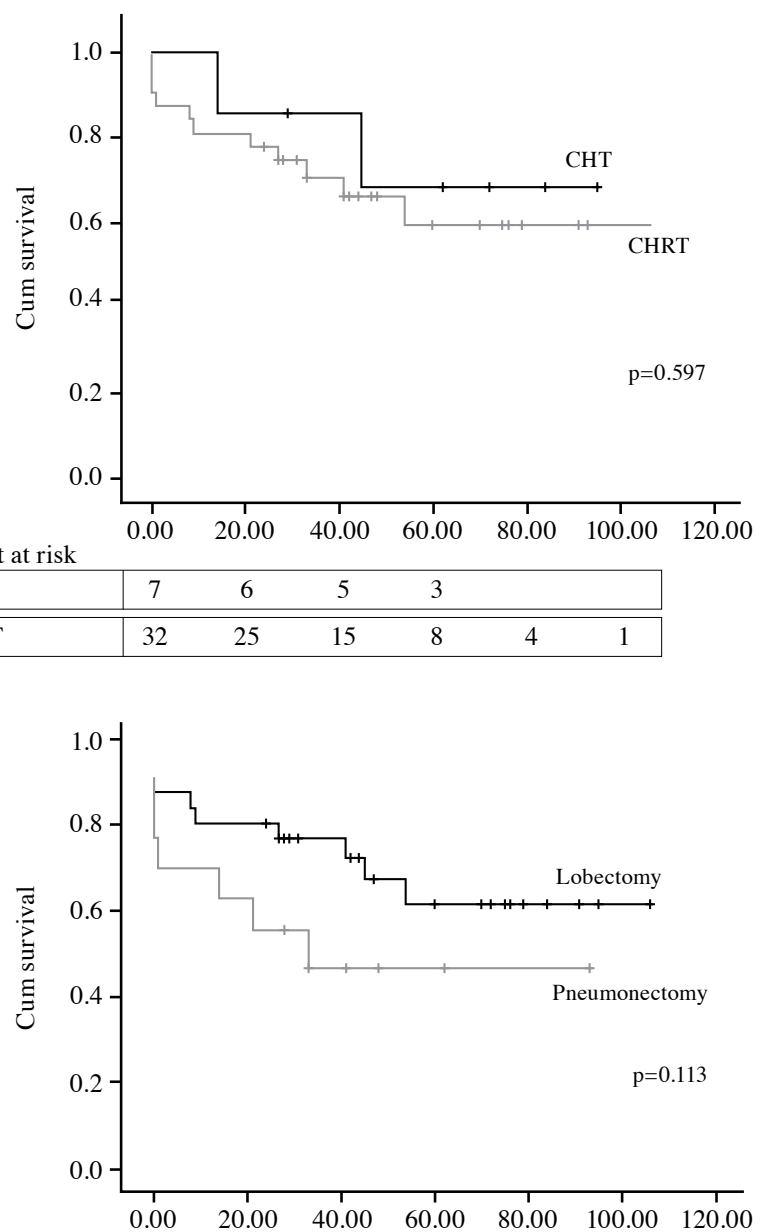

Patient at risk
\begin{tabular}{|l|cccccc|}
\hline Lobectomy & 26 & 23 & 17 & 10 & 5 & 1 \\
\hline \hline Pneumonectomy & 13 & 8 & 4 & 2 & 1 & \\
\hline
\end{tabular}

Figure 1. Kaplan-Meier curves of factors affecting survival. (a) General survival curve of complete response after IT. (b) Survival curve of complete response after chemotherapy or chemoradiotherapy $(\mathrm{p}=0.597)$. (c) Survival curve of $\mathrm{pN}$ status before the IT ( $\mathrm{p}=0.005)$. (d) Survival curve of resection types of the complete response after IT $(\mathrm{p}=0.113)$.

CHT: Chemotherapy; CHRT: Chemoradiotherapy; IT: Induction treatment. 
Table 4. Factors affecting DFS

\begin{tabular}{|c|c|c|c|c|}
\hline & $\begin{array}{c}\text { 5-year OS } \\
(\%)\end{array}$ & $\begin{array}{c}\text { Mean survival } \\
\text { (months) }\end{array}$ & $95 \% \mathrm{CI}$ & $p$ \\
\hline Side & & & & 0.144 \\
\hline Right & 60.3 & 71 & $54-89$ & \\
\hline Left & 45.9 & 46 & $28-63$ & \\
\hline $\mathrm{cN} 2$ & & & & 0.014 \\
\hline Single cN2 & 70.8 & 80 & $63-96$ & \\
\hline Multiple cN2 & 40 & 27 & $13-41$ & \\
\hline IT & & & & 0.274 \\
\hline $\mathrm{CHT}$ & 68.6 & 74 & $51-98$ & \\
\hline CHT-RT & 52.1 & 60 & $45-76$ & \\
\hline IT Chemotherapy cycles & & & & 0.658 \\
\hline 2 & 60 & 64 & $43-85$ & \\
\hline $4-6$ & 53.7 & 61 & $43-79$ & \\
\hline IT Radiotherapy dose & & & & 0.655 \\
\hline$\leq 60 \mathrm{~Gy}$ & 55 & 63 & $44-82$ & \\
\hline$>60 \mathrm{~Gy}$ & 49.5 & 32 & $25-43$ & \\
\hline Resection type & & & & 0.002 \\
\hline Lobectomy & 67.6 & 78 & $62-93$ & \\
\hline Pneumonectomy & 27.4 & 32 & $16-48$ & \\
\hline Adjuvant & & & & 0.658 \\
\hline Negative & 53.7 & 61 & $43-79$ & \\
\hline Positive & 60 & 64 & $43-85$ & \\
\hline
\end{tabular}

DFS: disease-free survival; OS: Overall survival; CI: Confidence interval; IT: Induction treatment; CHT: Chemotherapy; RT: Radiotherapy; Gy: Gray.

Table 5. Survival in patients with pCR following IT

\begin{tabular}{|c|c|c|c|c|c|c|}
\hline Author & Year & $\mathrm{n}$ & $\mathrm{pCR}(\mathrm{n})$ & $\mathrm{pCR}(\%)$ & IT protocol & $\begin{array}{c}\text { 5-year overall } \\
\text { survival (\%) }\end{array}$ \\
\hline DeCamp et al. ${ }^{[29]}$ & 2003 & 105 & 12 & 11.4 & CHT+RT (total dose: $60 \mathrm{~Gy}$ ) & N/A \\
\hline Machtay et al..$^{[8]}$ & 2003 & 53 & 7 & 13.2 & CHT+RT (total dose: 45-54 Gy) & $48(\mathrm{pCR}+\mathrm{pPR})$ \\
\hline Cerfolio et al. ${ }^{[21]}$ & 2009 & 216 & 71 & 32.8 & CHT+RT (total dose: $60 \mathrm{~Gy}$ ) & N/A \\
\hline Steger et al. ${ }^{[30]}$ & 2009 & 107 & 19 & 17.7 & CHT+RT (total dose: 45 Gy) & 56 \\
\hline Friedel et al. ${ }^{[28]}$ & 2010 & 120 & 15 & 12.5 & CHT+RT (total dose: 45 Gy) & 67 \\
\hline Weder et al. ${ }^{[26]}$ & 2010 & 176 & 36 & 20.4 & $\begin{array}{l}\text { CHT alone }(20 \%) . \text { CHT+RT }(80 \%) \\
\text { (total dose: } 45 \mathrm{~Gy})\end{array}$ & 56 \\
\hline Kim et al. ${ }^{[31]}$ & 2011 & 233 & 52 & 22.3 & CHT+RT (total dose: 43 Gy) & 58 \\
\hline Lococo et al. ${ }^{[10]}$ & 2012 & 137 & 37 & 27 & CHT+RT (total dose: 50 Gy) & 64 \\
\hline Mouillet et al. ${ }^{[19]}$ & 2012 & 492 & 41 & 8.3 & CHT alone & 80 \\
\hline Pless et al. ${ }^{[17]}$ & 2015 & 232 & 27 & 11.6 & $\begin{array}{l}\text { CHT alone (51\%). CHT+RT }(49 \%) \\
\text { (total dose: } 44 \mathrm{~Gy})\end{array}$ & N/A \\
\hline Counago et al. ${ }^{[18]}$ & 2018 & 247 & 32 & 13 & $\begin{array}{c}\text { CHT alone }(52.5 \%)+\text { CHT+RT }(47.4 \%) \\
\text { (total dose } 44-66 \mathrm{~Gy})\end{array}$ & N/A \\
\hline Melek et al. ${ }^{[22]}$ & 2019 & 416 & 72 & 17.3 & $\begin{array}{c}\text { CHT alone }(69 \%) . \text { CHT+RT }(31 \%) \\
(45-66 \mathrm{~Gy})\end{array}$ & 72 \\
\hline Current study & 2020 & 187 & 39 & 20.8 & $\begin{array}{c}\text { CHT alone }(18 \%) . \text { CHT+RT }(82 \%) \\
(45-66 \mathrm{~Gy})\end{array}$ & 61.2 \\
\hline
\end{tabular}

pCR: Pathologic complete response; IT: Induction treatment; CHT: Chemotherapy; RT: Radiotherapy; Gy: Gray; N/A: Not available; pPR: Pathologic partial response. 
lung recurrence in one patient. Evaluation of distant recurrences revealed that four patients had lung metastases in the contralateral lung, one had a recurrence in the contralateral lung, liver, and the adrenal gland, and the remaining one had brain metastasis. Median DFS was 76 (95\% CI: 42-109) months. The five-year DFS rate was $55.1 \%$. The type of resection and multiple pN2 was the prognostic factor affecting DFS. Factors affecting DFS are given in Table 4.

\section{DISCUSSION}

Researchers have suggested that, in patients with locally advanced NSCLC, surgical treatment alone or only oncological treatment have a lower success rate than combined treatment (IT + surgery) in disease control, local or distant recurrence rates, and long-term survival, and despite the related ongoing debate, combined treatments have found their place in clinical practice. ${ }^{[2,5,6,9,14-18]}$ In the multi-center, randomized study of European Organisation for Research and Treatment of Cancer-08012 (EORTC08012), combined treatment facilitated, simplified, and reduced surgical treatment by regressing primary cancer and mediastinal involvement, allowed metastases that were undefined at the beginning of treatment to be approachable and dealt with, led to better use of medications before surgery through the vascular integrity of the tumor, and the surgery prevented the possibility of any residual tumor tissue in locally advanced disease. ${ }^{[6]}$ Many studies have shown that, along with IT, better survival rates are obtained with downstaging or pCR..$^{[2,4,8,10,15,19-22]}$ The pCR rates in these studies are reported ranging from 4 to $34 \%$. In the present study, the pCR rate was $20.8 \%$. The discrepancy in the pCR rates can be explained as follows: (i) the differences in the definition of $\mathrm{pCR}$, (ii) treatment protocols of $\mathrm{CHT}$ or $\mathrm{CHT}+\mathrm{RT}$ given as IT, and (iii) histological types. As an example of the differences in the clinical definition of $\mathrm{pCR}$, Cerfolio et al. ${ }^{[23]}$ defined pCR as a $1 \%$ or less of viable tumor cells detected on pathological examination of the entire resected specimens. In the present study, pCR was defined as no residual tumor tissue and mediastinal lymph node metastases left behind.

Studies have shown that the addition of an RT protocol to IT increases the chances of obtaining $\mathrm{pCR}$, compared to patients receiving CHT only. In particular, in the European Society for Medical Oncology Clinical Practice Guidelines, it is stated that the rate of pCR is higher in patients undergoing CHT compared to those receiving CHT only. ${ }^{[16]}$ The reason for this finding is stated as more efficient locoregional control with the addition of RT and lower rates of local recurrence. In the study of Cerfolio et al., ${ }^{[9]}$ only $30 \%$ of patients could be performed surgical treatment following IT, and the reason was suggested to be insufficient treatment response. In this regard and in the light of recent guidelines, the main factor in overall survival, local control of disease, and conversion to surgical treatment is performing effective IT. In the 8805 study of the Southwest Oncology Group (SWOG), ${ }^{[2]}$ IT consisted of the full treatment dose of RT combined with platinum-based CHT, and compared to other studies, about $85 \%$ of patients were referred for surgery after IT. In the present study, 286 patients with locally advanced NSCLC were evaluated after IT, 187 (65\%) of whom were given the chance of surgical exploration, and a pCR was achieved in $39(20.8 \%)$ of these patients. In IT, combining RT and CHT increases the $\mathrm{pCR}$, and relevant studies have shown that $\mathrm{CHT}$ has no negative impact on mortality and morbidity. ${ }^{[25-27]}$ In the study of Galetta and Spaggiari, ${ }^{[25]}$ induction CHT led to a significant increase in the morbidity rates. However, the mortality rates were acceptable, given that the patients had advanced tumors. Similarly, Weder et al. ${ }^{[26]}$ reported mortality as $3 \%$ in their series consisting of patients who underwent surgical resection after IT. In the present study, IT, the dose of RT, and tumor diameter had no influence on mortality in patients with pCR. Accordingly, we believe that CHT increases the rate of $\mathrm{pCR}$, despite challenging surgical technique. We consider that the most important reason for the high mortality rates in patients undergoing pneumonectomy is due to the low number of patients and the higher postoperative complications in patients receiving $\mathrm{RT}$.

In the present study, the five-year survival rate in the pCR group was $61.2 \%$. The resection type, tumor size, adjuvant treatment, and the IT protocol had no influence on survival. In the literature, five-year survival rates vary between 48 and $80 \%$ in studies with pCR groups (Table 5). Friedel et al. ${ }^{[28]}$ performed a Phase II study and reported a five-year survival rate as $66.7 \%$ in the $\mathrm{pCR}$ group and, compared to patients without $\mathrm{pCR}$, the difference was statistically significant. Lococo et al. ${ }^{[10]}$ also showed that the type of resection and adjuvant treatment were significant factors for survival of patients with pCR. In the present study, adjuvant treatment and resection type had no influence on survival, contrary to the findings in the literature.

In the literature, patients with $\mathrm{pCR}$ are predominantly $\leq 65$ years old. ${ }^{[3]}$ Lococo et al. ${ }^{[10]}$ reported that the pCR response was similar in 
patients aged $\geq 65$ years, although the DFS time was found to be longer in those aged $\leq 65$ years than those $\geq 65$ years. In our study, the rate of patients aged $\geq 65$ years with pCR was found to be $10.3 \%$. However, the effect of geriatric age group on disease survival and DFS was not detected. We believe that the most important reason for pCR being detected more than $\geq 65$ years is the better performance of the patients and the fact that they are more adapted to CHT and RT.

In patients with locally advanced NSCLC, better survival results have been reported in patients with single N2 before IT than in those with multiple N2. ${ }^{[10,22,23]}$ Lococo et al. ${ }^{[10]}$ considered multiple pN2 as a poor prognostic factor in terms of survival. In our study, the five-year survival rate in singlestation N2 diseases was $76.7 \%$ in patients with $\mathrm{pCR}$, and the five-year survival rate in multiple $\mathrm{N} 2$ diseases was $40 \% \quad(p=0.005)$. On the other hand, resection type had no influence on survival in the present study; however, rates of DFS were better and significant in patients who underwent lobectomy. The reasons for the high survival rates in the present study can be explained as follows: (i) IT was given in accordance with recent guidelines and a Surgical Council (including a surgeon, clinician, oncologist, and physiotherapist) was formed with the aim of surgical patient selection after IT; thus the whole procedure was meticulous and deliberate, (ii) the patient population of the present study was heterogeneous and patients with locally advanced disease with superior sulcus tumors were included together with patients with $\mathrm{pN} 2$ disease, and (iii) postoperative follow-ups and rehabilitation were performed systematically.

In locally advanced disease, patients with an SqCC had higher rates of pCR. ${ }^{[19,22]}$ In the study of Melek et al., ${ }^{[2]}$ pCR was observed in 39 (16.4\%) of 238 patients who had an SqCC and underwent surgery after IT, and pCR was observed in nine (8.1\%) patients in 111 patients with an adenocarcinoma $(\mathrm{p}=0.024)$. Additionally, in the same study, only $28 \%$ of patients with an SqCC and $38.7 \%$ of patients with an adenocarcinoma were given CHT ( $p=0.018$ ). In the present study, $69.2 \%$ of patients with pCR had an SqCC, and histopathology type had no influence on survival $(\mathrm{p}=0.700)$.

The influence of IT on survival was evaluated in the pCR group, and the comparison of patients given CHT and those given CHT only revealed no significant difference. The five-year survival rates were calculated as $59.7 \%$ and $68.6 \%(p=0.59)$. Similarly, Higgins et al. ${ }^{[5]}$ performed IT as CHT in 31 patients and $\mathrm{CHT}+\mathrm{R}$ in 71 patients. Rates of $\mathrm{pCR}$ and survival were not statistically significantly different between the groups (CHT 41\%, CHT+RT 39\%) $(p=0.65)$. In the study of Melek et al., ${ }^{[22]}$ the rate of pCR was higher in patients given CHT+RT, although comparisons with $\mathrm{CHT}$ revealed no statistically significant difference in terms of survival. However, Toyooka et al. ${ }^{[32]}$ performed a study in 50 patients, and their patients who were given induction $\mathrm{CHT}+\mathrm{RT}$ $(n=35)$ had better survival rates, compared to patients given CHT only $(n=15) \quad(p=0.002)$. The $p C R$ was obtained in $20.6 \%$ of patients given $\mathrm{CHT}+\mathrm{RT}$, and in $6.7 \%$ of patients given CHT only.

Studies in the literature have reported low rates of recurrence in patient groups with pCR. ${ }^{[15,19,22]}$ Mouillet et al. ${ }^{[19]}$ reported recurrence as $4.8 \%$ and DFS as $80.1 \%$ in their pCR group, and the difference in DFS was statistically significant in their patients with SqCC and pCR. In the study of Melek et al., ${ }^{[22]}$ these same rates were reported as $23.6 \%$ and $72 \%$, respectively. However, the study of Lococo et al..$^{[10]}$ was different from the aforementioned studies, since recurrence was observed in $17(46 \%)$ patients. Their five-year DFS rate was $61 \%$, and DFS was statistically significantly different in patients given adjuvant treatment. In the present study, DFS was seen in $55.1 \%$ of patients, and recurrence was encountered in nine $(23.1 \%)$ patients. Analyses of these recurrences revealed that $66.6 \%$ were observed in distant organs. The most important factor influencing DFS was resection type and multiple $\mathrm{pN} 2$.

The retrospective nature of the study, the limited number of patients, and the fact that more than one surgeon was involved may have led to bias. In addition, $\mathrm{N} 2$ disease being a heterogeneous group is another bias. Multivariate analysis could not be performed due to the small number of patients. Due to the missing of the PET-CT data of patients, pCR rates were not specified in the study. Lack of information about the performance status of patients receiving IT and comparison of patient selection criteria in IT are other limitations. Furthermore, survival results could not be compared with the other non-small cell cancers, which can be deemed as another limitation.

In conclusion, multimodality treatment has a very important place in locally advanced disease; however, there is stillnoconsensusinthe literature. Theresults of the present study showed that, in patients with pathological complete response, resection type and induction chemotherapy and chemotherapy + radiotherapy did not affect survival. Although the surgical approach following induction chemotherapy + radiotherapy is 
challenging, the chances of pathological complete response and downstaging are increased. Additionally, chemotherapy + radiotherapy and chemotherapy have no effect on mortality. The most important prognostic factor in survival is the single-station N2. Therefore, we recommend that adjuvant therapy should be given to patients with multiple clinical $\mathrm{N} 2$ due to poor survival results, even if they have a pathological complete response. Nevertheless, further, prospective, randomized studies are needed to confirm these findings.

\section{Declaration of conflicting interests}

The authors declared no conflicts of interest with respect to the authorship and/or publication of this article.

\section{Funding}

The authors received no financial support for the research and/or authorship of this article.

\section{REFERENCES}

1. Sezen CB, Aksoy Y, Sonmezoglu Y, Citak N, Saydam O, Metin M. Prognostic factors for survival in patients with completely resected $\mathrm{pN} 2$ non-small-cell lung cancer. Acta Chir Belg 2021;121:23-9.

2. Song WA, Zhou NK, Wang W, Chu XY, Liang CY, Tian $\mathrm{XD}$, et al. Survival benefit of neoadjuvant chemotherapy in non-small cell lung cancer: An updated meta-analysis of 13 randomized control trials. J Thorac Oncol 2010;5:510-6.

3. Akyıl M, Tezel Ç, Tokgöz Akyıl F, Gürer D, Evman S, Alpay L, et al. Prognostic significance of pathological complete response in non-small cell lung cancer following neoadjuvant treatment. Turk Gogus Kalp Dama 2020;28:166-74.

4. Paul S, Mirza F, Port JL, Lee PC, Stiles BM, Kansler AL, et al. Survival of patients with clinical stage IIIA non-small cell lung cancer after induction therapy: Age, mediastinal downstaging, and extent of pulmonary resection as independent predictors. $\mathbf{J}$ Thorac Cardiovasc Surg 2011;141:48-58.

5. Higgins K, Chino JP, Marks LB, Ready N, D'Amico TA, Clough RW, et al. Preoperative chemotherapy versus preoperative chemoradiotherapy for stage III (N2) non-smallcell lung cancer. Int J Radiat Oncol Biol Phys 2009;75:1462-7.

6. Gilligan D, Nicolson M, Smith I, Groen H, Dalesio O, Goldstraw P, et al. Preoperative chemotherapy in patients with resectable non-small cell lung cancer: Results of the MRC LU22/NVALT 2/EORTC 08012 multicentre randomised trial and update of systematic review. Lancet 2007;369:1929-37.

7. Eberhardt WE, Albain KS, Pass H, Putnam JB, Gregor A, Assamura $\mathrm{H}$, et al. Induction treatment before surgery for nonsmall cell lung cancer. Lung Cancer 2003;42 Suppl 1:S9-14.

8. Machtay M, Lee JH, Stevenson JP, Shrager JB, Algazy KM, Treat J, et al. Two commonly used neoadjuvant chemoradiotherapy regimens for locally advanced stage III non-small cell lung carcinoma: Long-term results and associations with pathologic response. J Thorac Cardiovasc Surg 2004;127:108-13.
9. Cerfolio RJ, Maniscalco L, Bryant AS. The treatment of patients with stage IIIA non-small cell lung cancer from N2 disease: Who returns to the surgical arena and who survives. Ann Thorac Surg 2008;86:912-20.

10. Lococo F, Cesario A, Margaritora S, Dall'Armi V, Mattei F, Romano R, et al.Long-term results in patients with pathological complete response after induction radiochemotherapy followed by surgery for locally advanced non-small-cell lung cancer. Eur J Cardiothorac Surg 2013;43:e71-81.

11. Rusch VW, Asamura H, Watanabe H, Giroux DJ, Rami-Porta R, Goldstraw P; Members of IASLC Staging Committee. The IASLC lung cancer staging project: A proposal for a new international lymph node map in the forthcoming seventh edition of the TNM classification for lung cancer. $\mathrm{J}$ Thorac Oncol 2009;4:568-77.

12. Rami-Porta R, Goldstraw P. 25-The Eighth Edition of the Tumor, Node, and Metastasis Classification of Lung Cancer. In: Pass HI, Ball D, Scagliotti GV, editors. IASLC Thoracic Oncology. 2nd ed. Philadelphia: Elsevier Inc.; 2018. p. 253-64.

13. Charlson ME, Pompei P, Ales KL, MacKenzie CR. A new method of classifying prognostic comorbidity in longitudinal studies: Development and validation. J Chronic Dis 1987;40:373-83.

14. Sezen CB, Kocaturk CI, Bilen S, Kalafat CE, Cansever L, Dincer SI, et al. Long-term outcomes of carinal sleeve resection in non-small cell lung cancer. Thorac Cardiovasc Surg 2020;68:190-8.

15. Depierre A, Milleron B, Moro-Sibilot D, Chevret S, Quoix E, Lebeau B, et al. Preoperative chemotherapy followed by surgery compared with primary surgery in resectable stage I (except T1N0), II, and IIIa non-small-cell lung cancer. J Clin Oncol 2002;20:247-53.

16. Crinò L, Weder W, van Meerbeeck J, Felip E; ESMO Guidelines Working Group. Early stage and locally advanced (non-metastatic) non-small-cell lung cancer: ESMO Clinical Practice Guidelines for diagnosis, treatment and follow-up. Ann Oncol 2010;21 Suppl 5:v103-15.

17. Pless M, Stupp R, Ris HB, Stahel RA, Weder W, Thierstein $\mathrm{S}$, et al. Induction chemoradiation in stage IIIA/N2 nonsmall-cell lung cancer: A phase 3 randomised trial. Lancet 2015;386:1049-56.

18. Couñago F, Rodriguez de Dios N, Montemuiño S, Jové-Teixidó J, Martin M, Calvo-Crespo P, et al. Neoadjuvant treatment followed by surgery versus definitive chemoradiation in stage IIIA-N2 non-small-cell lung cancer: A multi-institutional study by the oncologic group for the study of lung cancer (Spanish Radiation Oncology Society). Lung Cancer 2018;118:119-27.

19. Mouillet G, Monnet E, Milleron B, Puyraveau M, Quoix E, David P, et al. Pathologic complete response to preoperative chemotherapy predicts cure in early-stage non-small-cell lung cancer: Combined analysis of two IFCT randomized trials. J Thorac Oncol 2012;7:841-9.

20. Coroller TP, Agrawal V, Narayan V, Hou Y, Grossmann P, Lee $\mathrm{SW}$, et al. Radiomic phenotype features predict pathological response in non-small cell lung cancer. Radiother Oncol 2016;119:480-6. 
21. Cerfolio RJ, Bryant AS, Jones VL, Cerfolio RM. Pulmonary resection after concurrent chemotherapy and high dose (60Gy) radiation for non-small cell lung cancer is safe and may provide increased survival. Eur J Cardiothorac Surg 2009;35:718-23.

22. Melek H, Çetinkaya G, Özer E, Yentürk E, Sevinç TE, Bayram AS, et al. Pathological complete response after neoadjuvant/induction treatment: Where is its place in the lung cancer staging system? Eur J Cardiothorac Surg 2019;56:604-11.

23. Cerfolio RJ, Bryant AS, Winokur TS, Ohja B, Bartolucci AA. Repeat FDG-PET after neoadjuvant therapy is a predictor of pathologic response in patients with non-small cell lung cancer. Ann Thorac Surg 2004;78:1903-9.

24. Albain KS, Rusch VW, Crowley JJ, Rice TW, Turrisi AT 3rd, Weick JK, et al. Concurrent cisplatin/etoposide plus chest radiotherapy followed by surgery for stages IIIA (N2) and IIIB non-small-cell lung cancer: Mature results of Southwest Oncology Group phase II study 8805. J Clin Oncol 1995;13:1880-92.

25. Galetta D, Spaggiari L. Early and long-term results of tracheal sleeve pneumonectomy for lung cancer after induction therapy. Ann Thorac Surg 2018;105:1017-23.

26. Weder W, Collaud S, Eberhardt WE, Hillinger S, Welter $\mathrm{S}$, Stahel R, et al. Pneumonectomy is a valuable treatment option after neoadjuvant therapy for stage III non-small-cell lung cancer. J Thorac Cardiovasc Surg 2010;139:1424-30.

27. Dogru MV, Sezen CB, Aker C, Girgin O, Kilimci U,
Erduhan S, et al. Evaluation of factors affecting morbidity and mortality in pneumonectomy patients. Acta Chir Belg 2020. [Online ahead of print]

28. Friedel G, Budach W, Dippon J, Spengler W, Eschmann SM, Pfannenberg $\mathrm{C}$, et al. Phase II trial of a trimodality regimen for stage III non-small-cell lung cancer using chemotherapy as induction treatment with concurrent hyperfractionated chemoradiation with carboplatin and paclitaxel followed by subsequent resection: A single-center study. J Clin Oncol 2010;28:942-8

29. DeCamp MM, Rice TW, Adelstein DJ, Chidel MA, Rybicki LA, Murthy SC, et al. Value of accelerated multimodality therapy in stage IIIA and IIIB non-small cell lung cancer. J Thorac Cardiovasc Surg 2003;126:17-27.

30. Steger V, Walles T, Kosan B, Walker T, Kyriss T, Veit S, et al. Trimodal therapy for histologically proven N2/3 non-small cell lung cancer: Mid-term results and indicators for survival. Ann Thorac Surg 2009;87:1676-83.

31. Kim AW, Liptay MJ, Bonomi P, Warren WH, Basu S, Farlow EC, et al. Neoadjuvant chemoradiation for clinically advanced non-small cell lung cancer: An analysis of 233 patients. Ann Thorac Surg 2011;92:233-41.

32. Toyooka S, Kiura K, Shien K, Katsui K, Hotta K, Kanazawa $\mathrm{S}$, et al. Induction chemoradiotherapy is superior to induction chemotherapy for the survival of non-smallcell lung cancer patients with pathological mediastinal lymph node metastasis. Interact Cardiovasc Thorac Surg 2012;15:954-60. 